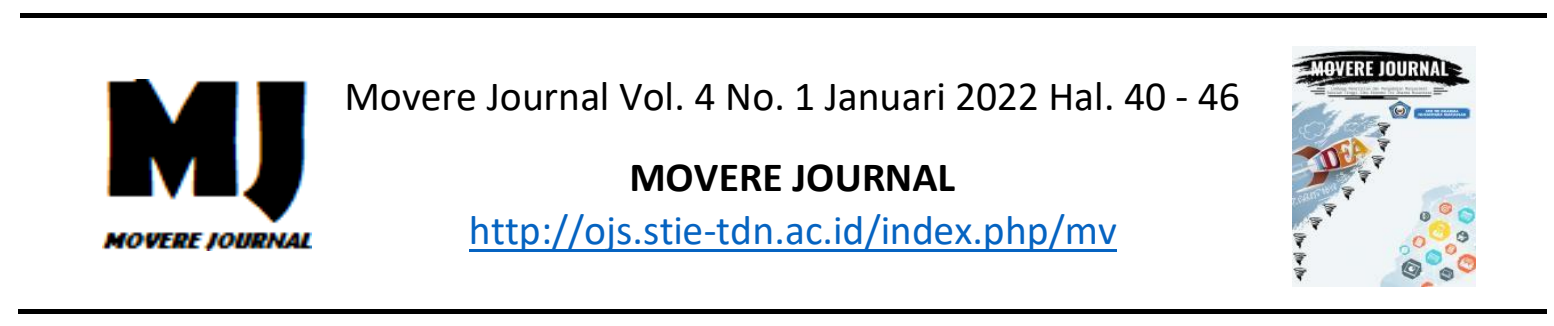

\title{
Penerapan Kompensasi Terhadap Kinerja Tenaga Kesehatan di Rumah Sakit Kota Makassar
}

\author{
${ }^{1}$ Ahmad Yusdarwin Waworuntu \\ ${ }^{1}$ Universitas Muslim Maros \\ ${ }^{1}$ Email : yos@umma.ac.id
}

\begin{abstract}
Abstrak: Penelitian ini dilaksanakan di Rumah Sakit Umum Daerah (RSUD) Haji Makassar yang beralamat di Jalan Daeng Ngeppe No.14 Kel. Jongaya Kec. Tamalate. Metode penelitian ini menggunakan pendekatan deskriptif kuantitatif. Teknik pengumpulan data menggunakan metode kuesioner. Analisi data dalam penelitian menggunakan analisis regresi linear berganda dengan jumlah sampel sebanyak 72 responden. Hasil penelitian ini menunjukkan: 1) Kompensasi berpengaruh positif dan signifikan secara parsial terhadap kinerja perawat pada Rumah Sakit Umum Daerah Haji Makassar.
\end{abstract}

Kata Kunci: kompensasi, kinerja

Abstract: This research was conducted at the Regional General Hospital (RSUD) Haji Makassar which is located at Jalan Daeng Ngeppe No.14 Kel. Jongaya district. Tamalate. This research method uses a quantitative descriptive approach. Data collection techniques using the questionnaire method. Data analysis in this study used multiple linear regression analysis with a sample of 72 respondents. The results of this study indicate: 1) Compensation has a positive and partially significant effect on the performance of nurses at the Makassar Haji Regional General Hospital.

Keywords : compensation; performance

\section{A. PENDAHULUAN}

Aset yang paling penting dalam sebuah organisasi adalah sumber daya manusia, karena pada dasarnya manusia sebagai faktor penggerak bagi setiap kegiatan dalam organisasi. Di era globalisasi sekarang ini, sumber daya manusia yang berkualitas dan mampu memenuhi tuntutan pekerjaan dalam suatu organisasi sangat dibutuhkan.

Berdasarkan Undang-Undang tenaga kesehatan No. 36 tahun 2014, pada pasal 11 ayat (1) dijelaskan bahwa tenaga kesehatan dikelompokkan kedalam: tenaga medis, tenaga psikologi klinis, keperawatan, kebidanan, kefarmasian, kesehatan 
masyarat, kesehatan lingkungan, keterapian fisik, keteknisian medis, teknik medis, teknis biomedika, kesehatan tradisional dan kesehatan lain. Pasal 62 ayat (1) tenaga kesehatan dalam menjalankan praktik harus dilakukan sesuai dengan kewenangan yang didasarkan pada kompetensi yang dimilik

Rumah sakit dibentuk untuk melayani konsumen dibidang kesehatan dengan pelayanan profesional. Dalam pencapaian tujuan, maka diharapkan kinerja perawat pada RSUD Haji Makassar dapat terus meningkat. Akan tetapi pada kenyataannya kinerja perawat pada RSUD Haji Makassar mengalami pasang surut. Sehingga dalam hal ini kinerja karyawan merupakan suatu hal yang sangat penting dalam pencapaian tujuan secara optimal. Untuk mencapai tujuan tersebut, maka manajer perlu memberikan daya pendorong terhadap para perawat. Daya pendorong tersebut diantaranya adalah kompensasi.

Motivasi merupakan dorongan, keinginan, hasrat dan tenaga penggerak yang berasal dari diri manusia untuk berbuat atau untuk melakukan sesuatu (Wursanto:2005). Dengan motivasi yang tinggi akan menciptakan sebuah komitmen terhadap apa yang menjadi tanggung jawabnya dalam menyelesaikan setiap pekerjaan. Motivasi kerja perawat, dimana motivasi kerja yang baik akan dapat berdampak kepada kinerja yang semakin meningkat. Untuk meningkatkan motivasi kerja perawat organisasi biasanya memberikan kompensasi. Kompensasi merupakan hal penting yang merupakan dorongan atau motivasi utama seorang perawat untuk bekerja.

\section{B. TELAAH LITERATUR DAN PENGEMBANGAN HIPOTESIS}

Pada dasarnya manusia bekerja juga ingin memperoleh uang untuk memenuhi kebutuhan hidupnya. Untuk itulah seorang karyawan mulai menghargai kerja keras dan semakin menunjukkan loyalitas terhadap perusahaan dan karena itulah perusahaan memberikan penghargaan terhadap prestasi kerja karyawan yaitu dengan jalan memberikan kompensasi. Salah satu cara manajemen untuk meningkatkan prestasi kerja, memotivasi dan meningkatkan kinerja para karyawan adalah melalui kompensasi (Mathis dan Jackson, 2010:52).

\section{Kompensasi}

Kompensasi adalah segala sesuatu yang dikonstitusikan atau dianggap sebagai suatu balas jasa atau ekuivalen (Sikula, 2010:14). Menurut William B.werther dan keith davis, kompensasi adalah apa yang seorang pekerja terima sebagai balasan dari pekerjaan yang diberikannya. Baik upah per jam atau gaji periodik diesain dan dikelola oleh bagian pesonalia. Melayu S.P. Hasibuan(2012:118) kompensasi adalah semua pendapatan yang berbentuk uang, barang langsung atau tidak langsung yang diterima karyawan sebagai imbalan atas jasa yang diberikan kepada perusahaan.

Kompensasi merupakan suatu yang dipertimbangkan sebagai suatu yang seimbang. Dalam kepegawaian, hadiah yang bersifat uang merupakan kompensasi yang diberikan kepada pegawai sebagai penghargaan dari pelayanan mereka. Pemberian upah merupakan imbalan, pembayaran untuk pelayanan yang telah diberikan oleh pegawai. Sangat banyak bentuk-bentuk pembayaran upah, baik berupa uang maupun yang bukan merupakan uang (non financial) (Mangkunegara, 2008).

Tujuan pemberian balas hendaknya memberikan kepuasan kepada semua pihak, karyawan dapat memenuhi kebutuhannya, pengusaha mendapat laba, peraturan pemerintah harus ditaati dan konsumen 
mendapat barang yang baik dan harga yang pantas.

Tujuan pemberian kompensasi antara lain adalah sebagai berikut :1) Ikatan kerja sama. Dengan pemberian kompensasi terjalinlah ikatan kerja sama formal antara majikan dengan karyawan. Karyawan harus mengerjakan tugas-tugasnya dengan baik, sedangkan pengusaha atau atasan wajib membayar kompensasi sesuai dengan perjanjian yang disepakati. 2) Kepuasan kerja. Dengan balas jasa, karyawan akan dapat memenuhi kebutuhan-kebutuhan fisik, status sosial, dan egoistiknya sehingga memperoleh kepuasan kerja dari jabatannya.

3)Pengadaan efektif. Jika program kompensasi ditetapkan cukup besar, pengadaan karyawan yang qualified untuk perusahaan akan lebih mudah.4) Motivasi. Jika balas jasa yang diberikan cukup besar, manajer akan mudah memotivasi bawahannya. 5) Stabilitas karyawan. Dengan program kompensasi atas prinsip adil dan layak serta eksternal konsistensi yang kompentatif maka stabilitas karyawan lebih terjamin karena turn-over relative kecil. 6) Disiplin. Dengan pemberian balas jasa yang cukup besar maka disiplin karyawan semakin baik. Mereka akan menyadari serta mentaati peraturan-peraturan yang berlaku. 7) Pengaruh serikat buruh. Dengan program kompensasi yang baik pengaruh serikat buruh dapat dihindarkan. 8) Pengaruh pemerintah. Jika program kompensasi sesuai dengan undang-undang perburuhan yang berlaku (seperti batas upah minimum) maka intervensi pemerintah dapat dihindarkan.

\section{Kinerja}

Kinerja pada dasarnya merupakan perilaku nyata yang dihasilkan setiap orang sebagai prestasi kerja yang dihasilkan oleh karyawan sesuai dengan perannya dalam perusahaan. Untuk mendapatkan kinerja yang baik dari seorang karyawan pada sebuah organisasi harus dapat memberikan sarana dan prasarana sebagai penunjang dalam menyelesaikan pekerjaan. Istilah kinerja sendiri merupakan tujuan dari kata Job Performance atau Actual Performance (prestasi kerja atau prestasi sesungguhnya yang dicapai oleh seseorang).

Menurut Syamsir Torang (2013: 74) kinerja (performance) adalah kualitas atau kualitas hasil kerja individu atau sekelompok di dalam organisasi dalam melaksanakan tugas pokok dan fungsi yang berpedoman pada norma, standar operasional prosedur, kriteria dan ukuran yang telah ditetapkan atau yang berlaku dalam organisasi. Menurut Suyadi Prawirosentoso dalam Akhmad Subekhi dan Mohamad Jauhar (2012: 193), kinerja adalah hasil kerja yang dapat dicapai oleh seseorang atau sekelompok orang dalam suatu organisasi, sesuai dengan wewenang dan tanggungjawab masing-masing, dalam rangka upaya mencapai tujuan organisasi bersangkutan secara legal, tidak melanggar hukum dan sesuai dengan norma maupun etika. Menurut Mangkunegara (2009: 9), kinerja karyawan (prestasi) adalah hasil kerja secara kualitas dan kuantitas yang dicapai oleh seseorang karyawan dalam melaksanakan tugasnya sesuai dengan tanggung jawab yang diberikan kepadanya.

Berdasarkan pengertian di atas, dapat ditarik kesimpulan bahwa kinerja pegawai adalah hasil kerja yang dicapai oleh pegawai dalam suatu organisasi sesuai dengan wewenang dan tanggung jawab masing-masing dan diselesaikan dengan waktu yang telah ditentukan, kecakapan pegawai, pengalaman, kualitas, dan kuantitas guna mencapai visi, misi, dan tujuan 
organisasi. Kinerja dapat dikatakan tinggi apabila target dapat diselesaikan dengan waktu yang tepat, sedangkan kinerja dikatakan rendah apabila diselesaikan melampaui batas waktu yang telah ditentukan.

Gambar 1. Kerangka Konseptual

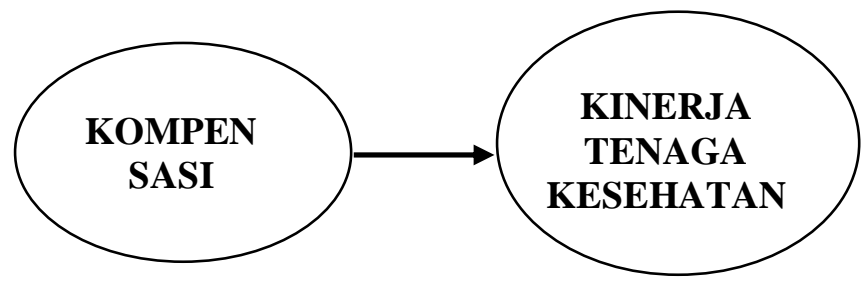

\section{METODE PENELITIAN}

Bagian ini menjelaskan tentang metode/pendekatan yang digunakan, misalnya penelitian kualitatif atau kuantitatif atau mix method. Selanjutnya dijelaskan langkah penelitian yang dilakukan sampai mendapatkan data, misalnya menggunakan kuesioner atau wawancara atau observasi atau ketiga-tiganya, dll sehingga metodologi jelas tergambar pada poin ini.

Selanjutnya jelaskan tentang populasi dan sampel penelitian yang dilakukan secara detail, kalau perlu dilengkapi tabel populasi dan sampel atau dijelaskan secara detail sehingga jelar siapa populasinya, sampelnya berapa dan bagaimana menentukan sampel dan responden/informannya. (font Times New Roman dengan ukuran 12).

\section{HASIL DAN PEMBAHASAN}

Penelitian ini termasuk dalam penelitian asosiatif kausal dengan menggunakan pendekatan kuantitatif. Penelitian asosiatif kausal adalah penelitian yang bertujuan untuk mengetahui pengaruh antara dua variabel atau lebih. Penelitian ini akan menjelaskan hubungan memengaruhi dan dipengaruhi dari variabel-variabel yang akan diteliti. Pendekatan kuantitatif digunakan karena data yang digunakan akan menganalisis hubungan antar variabel yang dinyatakan dengan angka. Penelitian ini menghubungkan pengaruh kompensasi, motivasi dan stres kerja terhadap kinerja perawat.

Penelitian pada RSUD Haji Makassar yang beralamat di Jl. Dg. Ngeppe No.14, Balang Baru, Kec. Tamalate, kota Makassar Sulawesi Selatan. Adapun yang menjadi objek penelitian adalah tenaga kesehatan RSUD Haji Makassar

Populasi adalah sekumpulan individu atau objek penelitian yang memiliki kualitas serta ciri-ciri yang telah ditetapkan berdasarkan kualitas dan ciri-ciri tersebut (Arikunto: 2013). Adapun populasi yang dimaksud dalam penelitian ini adalah para perawat pada RSUD Haji Makassar dengan jumlah keseluruhan populasi 250 orang.

Sampel adalah sebagian dari populasi itu. Sampel merupakan suatu cara dalam pengumpulan data yang sifatnya tidak menyeluruh, akan tetapi sebagian saja dari populasi (Sugiyono: 2012). Karena keterbatasan waktu, tenaga dan biaya serta jumlah populasi melebihi 100 maka untuk menentukan sampel dari jumlah populasi tersebut menggunakan rumus Slovin dengan rumus sebagai berikut (Husein umar: 2008) : dibulatkan menjadi 72 orang.

Teknik

Sampling Penggunaan sampel bertujuan untuk mengefisiensikan waktu penelitian. Untuk menentukan sampel yang akan digunakan dalam penelitian ini digunakan teknik sampling. Simple random sampling dinyatakan simple karena pengambilan sample anggota populasi dilakukan secara acak tanpa memperhatikan strata yang ada dalam populasi itu. Simple random sampling merupakan teknik untuk 
mendapatkan sample yang langsung dilakukan pada unit sampling. Maka setiap unit sampling sebagai unsur populasi yang terpencil memperoleh peluang yang sama untuk menjadi sampel atau untuk mewakili populasinya (Sugiyono: 2013).

\section{Instrumen Penelitian}

Validasi adalah suatu skala pengukuran disebut valid bila melakukan apa yang seharusnya diukur. Bila skala pengukuran tidak valid maka tidak bermanfaat bagi peneliti karena tidak mengukur atau melakukan apa yang seharusnya dilakukan (Gozali 2013: 97).

Reabilitas adalah alat untuk mengukur suatu kuesioner yang merupakan indicator dari variabel. Butir pertanyaan dikatakan reliable atau andal apabila jawaban seseorang terhadap pertanyaan adalah konsisten. Pengukuran reabilitas dapat dilakukan dengan cara pengukuran sekali kerja. Pengukuran keandalan butir pertanyaan dengan sekali menyebar kuesioner pada responden, kemudian hasil skornya diukur korelasinya antar skor jawaban pada butir pertanyaan yang sama dengan bantuan komputer Statistical Program For Society Science (SPSS), dengan Fasilitas Cronbach Alpha (a). Suatu konstruk atau variabel dikatakan reliable jika memberikan nilai alpha>0,60 (Gozali:2013).

\section{Teknik Pengumpulan Data}

Data yang diperlukan dalam penelitian ini adalah data tentang pengaruh kompensasi, motivasi dan stress kerja terhadap kinerja perawat. Pengumpulan data dalam penelitian ini dilakukan dengan:

Observasi, yaitu melakukan pengamatan secara langsung terhadap aktivitas keseharian, lingkungan dan sasaran kerja yang berhubungan dengan penulisan ini.

Metode Kepustakaan (Library Research), Metode kepustakaan adalah mengumpulkan data dengan membaca buku- buku yang relevan untuk membantu didalam menyelesaikan dan juga untuk melengkapi data yang berhubungan dengan masalah yang dibahas

Daftar pertanyaan, metode pengumpulan data yang akan digunakan dalam penelitian ini adalah menggunakan kuesioner secara personal. Data dikumpulkan dengan menggunakan kuesioner (angket), yaitu angket yang digunakan untuk mendapat data tentang kompensasi, motivasi dan stres kerja dalam usahanya untuk meningkatkan kinerjanya. Adapun proses untuk mendapatkan data yang akurat maka diperlukan skala likert untuk mengangkakan setiap pertanyaan yang digunakan dalam kuesioner penelitian yang peneliti lakukan. Skala likert dapat digunakan untuk mengukur sikap, pendapat dan persepsi seseor ang atau kelompok orang tentang fenomena tertentu. Angket dalam penelitian ini menggunakan skala likert dengan lima pilihan jawaban, yaitu :

Sangat Setuju $(\mathrm{SS})=5$

Setuju $(S)=4$

Kurang Setuju $(\mathrm{KS})=3$

Tidak Setuju $(\mathrm{TS})=2$ $=1$

Sangat Tidak Setuju (STS)

\section{Teknik Analisis Data Dan Uji Hipotesis}

Teknik analisis data,Regresi linear berganda ditujukan untuk menentukan hubungan linear antar beberapa variabel bebas yang biasa disebut X1, X2, X3 dan seterusnya dengan variabel terikat yang disebut Y (Situmorang,2008). Data yang telah dihimpun kemudian di analisis dengan menggunakan regresi berganda untuk mengetahui ada 
tidaknya pengaruh variabel bebas, yang terdiri kompensasi, motivasi dan stress kerja, variabel terikat yaitu kinerja perawat. Analisis regresi linear berganda digunakan untuk mengetahui pengaruh kompensasi (X1), motivasi(X2), dan stress kerja (X3) terhadap kinerja perawat (Y). Model persamaannya adalah sebagai berikut:

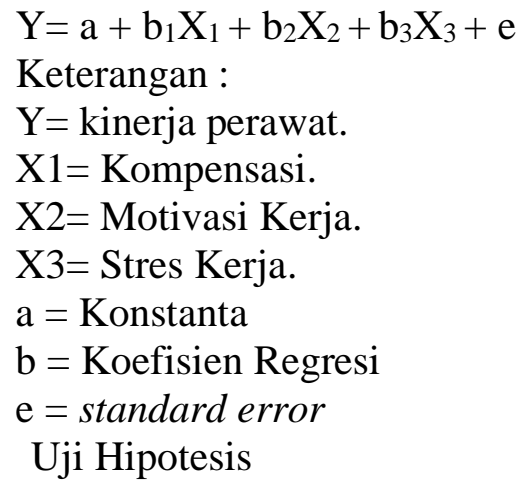

Uji hipotesis dilakukan untuk menjawab apa yang menjadi rumusan pada penelitian. Pada penelitian ini tepatnya pada analisis inferensial digunakan analisis regresi linear berganda yang telah dijelaskan sebelumnya.

Uji Koefisien Determinasi ( $\mathrm{R}^{2}$ )Uji koefisien determinasi $\left(\mathrm{R}^{2}\right)$ digunakan untuk mengetahui kontribusi variabel bebas dalam menjelaskan variabel terikat. Semakin besar nilai koefisien determinasi, maka menunjukkan semakin besar pula pengaruh variabel independen terhadap variabel dependen

Uji Model atau uji-f (goodness of fit test)Untuk menguji apakah pengaruh kompensasi, motivasi dan stress kerja secara simultan memiliki pengaruh terhadap kinerja perawat, maka dilakukan uji F.HO : $\beta 1=0$, variabel independen (X) secara simultan berpengaruh tidak signifikan terhadap variabel dependen $(\mathrm{Y}) \mathrm{HO}: \beta 1 \neq 0$, Variabel independen $(\mathrm{X})$ secara simultan berpengaruh signifikan terhadap variabel dependen (Y).Uji Parsial (Uji t/ t-student)Pengujian koefisien secara parsial adalah untuk mengetahui pengaruh masing-masing variabel independen secara parsial (sendiri) terhadap variabel dependennya. Dengan pernyataan Hipotesis sebagai Berikut:

- Ho $\quad: \beta 1 \geq 0$ artinya Variabel independen $(\mathrm{X})$ berpengaruh tidak signifikan terhadap Variabel Dependen (Y)

- Ha : $\beta 1<0$ artinya Variabel independen $(\mathrm{X})$ berpengaruh signifikan terhadap Variabel Dependen (Y).

Hasil analisis regresi berganda dengan menggunakan uji parsial didapatkan bahwa ada pengaruh positif dan signifikan antara kompensasi dengan kinerja perawat, ini ditandai dengan nilai $\mathrm{t}$ hitung yang lebih besar dari t tabel yaitu 6,597> 1,66757 dan nilai peluang (sig.) pengujian sebesar 0,000 yang lebih kecil dari 0,05. Hasil tersebut menunjukkan bahwa kompensasi berpengaruh positif dan signifikan terhadap kinerja perawat pada Rumah Sakit Umum Daerah (RSUD) Haji Makassar. Kompensasi merupakan hal yang sangat penting bagi perawat karena menurut mereka jumlah atau besaran kompensasi dapat merepresentasikan nilai dari suatu kinerja. Dengan demikian kompensasi perlu untuk mencapai kinerja yang lebih baik.

Hasil penelitian ini juga diperkuat oleh Rafi Jody Kurnia (2016), bahwa kompensasi dan motivasi berpengaruh terhadap kinerja karyawan. Dengan demikian, dapat ditarik kesimpulan bahwa kompensasi berpengaruh terhadap kinerja perawat. Walaupun tidak semua perawat yang mendapatkan kompensasi dapat memcapai kinerja yang tinggi, tetapi kompensasi dapat dijadikan faktor untuk memacu kinerja perawat 


\section{E. KESIMPULAN}

Kesimpulan, hasil penelitian menunjukkan nilai koefisien regresi parsial dari kompensasi (X1) berpengaruh secara positif dan signifikan terhadap kinerja perawat pada Rumah Sakit Umum Daerah (RSUD) Haji Makassar. Hal ini dibuktikan dengan nilai t hitung yang lebih besar dari nilai $t$ tabel $(6,597>1,66757)$ dan nilai peluanga (sig.) yang lebih kecil dari $\alpha$ $(0,000<0.05)$.

Saran, sebaiknya pihak rumah sakit menambah gaji, bonus, fasilitas agar kinerja perawat lebih efektif. Sebaiknya pihak rumah sakit lebih meningkatkan motivasi yang positif kepada perawat agar kinerja semakin meningkat.

\section{DAFTAR PUSTAKA}

2002. Manajemen sumber daya manusia. Jakarta : PT.Bumi Aksara

Abdullah ma'ruf. 2014. Manajemen dan evaluasi kinerja karyawan. Yogyakarta : Aswaja Pressindo

Akhmad F. 2016. "Pengaruh Sters Kerja, Motivasi Dan Kompensasi Terhadap Kinerja Karyawan Cv. Auto Nusa Abadi Kupang" tesis program pacasarjana universitas terbuka Jakarta

Arsyad Azhar.2003. pokok-pokok manajemen. Yogyakarta : pustaka pelajar

Daft, Richard L. 2003. manajemen. Edisi kelima. Jakarta : erlangga

Dewi K.P. 2017. "Pengaruh kompensasi, motivasi dan stress kerja terhadap kinerja karyawan pada BNI syariah KC Surakarta", Skripsi fakultas ekonomi dan bisnis Islam institut agama islam negeri salatiga.

Farlen frans. 2011. Pengaruh motivasi kerja dan kemampuan kerja terhadap kinerja karyawan pada PT.United Tractors tbk Samarinda. Skripsi fakultas ilmu sosial dan ilmu politik universitas pembangunan nasional Yogyakarta.

Fitriani, nita.2016. "pengaruh kompensasi dan stress kerja terhadap kinerja karyawan perbankan syariah". Skripsi fakultas ekonomi dan bisnis universitas islam negeri syarif hidayatullah

Gaffar, H. 2012. Pengaruh stres kerja terhadap kinerja karyawan pada PT. Bank mandiri (PERSERO) tbk kantor Wilayah X Makassar. Skripsi fakultas ekonomi dan bisnis Universitas Hasanuddin Makassar.

Hasibuan, melayu S P. 2001. Manajemen dasar, pengertian, dan masalah. Edisi revisi. Jakarta : PT. Bumi Aksara

http://fandiprasetiyo.blogspot.com.

Diakses pada 19.35 WITA tanggal 4 November 2019. 